\title{
Introduction: Agrarian change, rural poverty and land reform in South Africa since 1994
}

\author{
Bridget O’Laughlin, Henry Bernstein, Ben Cousins and Pauline E. Peters
}

\begin{abstract}
This introduction sketches the context and dynamics of agrarian change, rural poverty and land reform since the end of apartheid in 1994, drawing attention to structural continuities and new elements in the countrysides of South Africa, and of the Southern African region in which South Africa must be located. Two key historical and theoretical reference points help focus attention on some central issues: the 'classic' model of dispossession/accumulation in South(ern) Africa, and 'decentralized despotism' as the distinctive mode and legacy of colonial governance. In conclusion, we introduce the papers as contributions to answering some central questions which require further research and debate.
\end{abstract}

\section{Introduction}

The 'Land Question' in post-apartheid South Africa retains a powerful political charge, given the continuing depth of rural poverty and the manner in which a long history of racialized land dispossession can be invoked as a potent symbol of historical injustice and oppression in general. Some argue that the ability to use even small plots of land for cultivation, for food provisioning and for sale has promise for rural residents (see Altman et al. 2009: see also Aliber and Cousins, this issue; Cousins, this issue). Others are sceptical about the potential of land reform to support smallholder farming, intensify agricultural production, generate employment and reduce poverty (Sender and Johnston 2004; echoed by Marais 2011, 218). Even the sceptics, however, acknowledge the political necessity of resolving (or defusing) the 'Land Question', and public commentary often refers to the spectre of Zimbabwe-style land invasions as a warning of what might happen should land reform fail. ${ }^{1}$ Land reform can thus be seen as simultaneously both central and marginal (or 'necessary but not sufficient') to meeting South Africa's crises of employment, livelihood and social reproduction, and tensions within and between its political, social and economic dimensions permeate both public discourse and scholarly analysis. ${ }^{2}$ Fuelling these controversies is the slow pace of land reform since the transition to democracy in 1994 in terms of transforming the racialized pattern of ownership of productive land, and even more so in terms of reconfiguring an agrarian structure dominated by large commercial farms. These challenges

\footnotetext{
${ }^{1}$ For example, 'ANCYL warns of Zim-style land invasions in South Africa' (http://mg.co.za/article/2012-06-05-ancylland-reform/), 'Minister warns farmers to co-operate', Pieter du Toit, News 24 (http://www.news24.com/SouthAfrica/Politics/Minister-warns-farmers-to-co-operate-201003290) and 'Land reform cannot be wished away' (http://fstimes.co.za/?p=9712) (all accessed on 13 March 2012).

${ }^{2}$ For sensitive and incisive analysis of such tensions, see Walker (2008).
} 
for land reform and agrarian transformation are elaborated below. First, we seek to situate South Africa within the region.

The Southern African region is deeply marked by its distinctive histories of colonial conquest and dispossession, and their uneven trajectories of capitalist accumulation and development. Questions of land and agrarian bases of livelihood have always been central to those histories in complicated and shifting ways connected with the organization of labour supply for the region's mining industries, above all in South Africa, from the late nineteenth century (the original moment of modern imperialism, in Lenin's sense) and for subsequent, if unevenly distributed, settler commercial agriculture, manufacturing industry and urbanization. The legacies of colonial dispossession remain evident in issues of land, and the struggles that they continue to generate, in the region today. Some countries achieved independence from colonial rule or national liberation later than most of sub-Saharan Africa: in the 1970s, following armed struggle in areas of the countryside (Angola, Mozambique, Zimbabwe), and in the early 1990s, in the new conjuncture of post-Soviet, post-Cold War 'globalization' (Namibia, South Africa).

Since independence/national liberation, the transformation of racialized patterns of land ownership of colonial and apartheid provenance has been slow throughout the region, not least in South Africa since 1994 (Mozambique since 1975 and Zimbabwe since 2000 are the striking exceptions).This does not mean, however, that there has been little change in rural areas, as we elaborate later in this Introduction, and as a number of the papers collected here show.

Issues of land distribution and of the contributions of farming, actual and potential, to livelihood continue to be asserted in a context of generalized crises of social reproduction, of persistent extreme poverty and growing inequality. The simplifying scales and measures of poverty and inequality applied to the countrysides of the region in the past 20 years or so present a bleak picture. Overall, South Africa's Gini coefficient for income distribution stood at 0.56 in 1995 and widened to 0.73 by 2005-6; without social grants (see below), it would have been 0.8 (Marais 2011, 208). Poverty continues to be concentrated in rural areas, and in the former Bantustans in particular, though it is increasingly marked in the burgeoning slum areas about cities. As in the mid-1990s, many of the poorest and most vulnerable continue to be young, female and black (Standing et al. 1996; Philip 2009, 2), while the growth of large cohorts of unemployed and desperate young men pose the same dangers as documented in other African countries (Chauveau and Richards 2008; Amanor 2010).

Confronting that bleakness, how might a broader and more radical approach to agrarian reform address questions of poverty and inequality in, and beyond, South Africa today? Demands for an immediate redistribution of white commercial farms can make good political rallying calls, 3 but tough questions remain: by what means, in what ways, and how much can agrarian reform address the processes that underlie rural and urban poverty and the increasing inequality that marks contemporary South Africa?

\footnotetext{
3 'ANC Youth League and Contralesa issue joint media statement after a bi-lateral meeting' (http://www.ancyl.org.za/show.php?id=8100) (accessed 13 August 2012). CONTRALESA is the Congress of Traditional Leaders of South Africa.
} 
This collection provides no definitive answer to these questions, but locates them in processes of agrarian change past and present, seeking to identify and explore complex connections and disconnections between rural and urban sources of income, agricultural and non-agricultural livelihoods, the multiple uses and significance of land, and large-scale and small-scale farming in Southern Africa. Most of the papers presented here address South Africa specifically, but in our view it is critical to maintain and develop a regional perspective, as several of our contributors illustrate. A number of the papers reflect the research agenda of the Institute of Poverty, Land and Agrarian Studies (PLAAS) of the University of the Western Cape since its inception in 1995.4 Most of the contributions by PLAAS researchers and others associated with PLAAS were presented in earlier versions at a colloquium on 'Land Reform, Agrarian Change and Rural Poverty in Southern Africa', held in Stellenbosch in March 2011.5

In some respects, this collection may be regarded as a sequel to a special issue of the Journal of Peasant Studies on The Agrarian Question in South Africa (Bernstein 1996a), produced in the moment of the 'transition' from apartheid from 1990 to 1994 and its challenges and debates, hopes and fears. The introduction to that previous collection (Bernstein 1996b) provided an outline account of South Africa's modern history, with special reference to agrarian change, an exercise that we do not repeat here. As points of entry for our concerns, we draw attention in much more selective fashion to some aspects of that history and the literatures that have addressed it; in particular, the 'classic' Southern African dispossession/accumulation model and Mahmood Mamdani's potent intervention on forms of political rule in colonial and postcolonial sub-Saharan Africa.

This collection updates the earlier one, drawing on recent and current research that has much to say, both empirically and analytically, about the conditions of existence and social dynamics of many black South Africans, the poverty, inequality and pressures on reproduction that they confront, and their struggles.

\section{Colonial dispossessions in southern Africa: legacies and change}

What is specific about the forms of domination in Southern Africa is not just the importance of its legacies of settler colonialism, but also the enduring legacy of politically organized regional systems of migrant labour. Land was carved up and its inhabitants sorted out, in state-regulated and often highly coercive systems of recruitment, as migrant workers or as small-scale commodity producers, or sometimes both at different points in their lives. Southern Africa is a region in which the movement of workers and goods has constantly breached the boundaries between rural and urban, and between states. Land expropriation, pass laws, price controls and licensing and other marketing arrangements regulated the terms of this movement but they did not stop it, nor were they intended to do so.

The histories of regional interconnection live on in the present in the dense movements of people, goods, ideas and infections across the political boundaries of Southern Africa. Some of these interconnections are obvious in contemporary everyday life. Young Zimbabwean men, perhaps mainly those with primary schooling, sleep rough in the countryside of Gaza province in

\footnotetext{
${ }^{4}$ Originally the Programme for Land and Agrarian Studies, PLAAS changed its title to the Institute for Poverty, Land and Agrarian Studies in 2009, but retained its distinctive acronym, which means 'farm' in Afrikaans.

${ }^{5}$ The colloquium was held at STIAS on 8-9 March 2011, organized by PLAAS, co-hosted by STIAS and funded by the DST/NRF Research Chair in Poverty, Land and Agrarian Studies held by Ben Cousins.
} 
Mozambique, competing with women for casual agricultural jobs. Other young Zimbabwean women and men, many with secondary and tertiary education, compete for work with less skilled South Africans in Limpopo or do 'business' in the townships. The recent attacks on migrants reveal the tense struggles over work and livelihoods. ${ }^{6} 6$ Skilled miners from Lesotho and Mozambique compete with South Africans for regular jobs, but there are fewer of these, as so many kinds of work are now contracted out to labour brokers. Small fruit and vegetable producers in Malawi, Mozambique and Zambia find their access to urban markets blocked by the neatly packaged South African produce imported by supermarket chains with higher volumes and lower transport costs (Miller 2008). South African capital also supports the acquisition of land for tourism ventures and biofuel production schemes throughout the region (Hall 2011). AIDS prevention models tried out in South Africa filter through both donor and civil society circuits as 'best practice', with dubious results, in other countries in the region, most of which have a very high incidence of HIV infection.

On one hand, rural poverty across the Southern Africa region today has some common characteristics: declining wage labour opportunities relative to population size means that wage remittances can support many fewer rural households than in the past; small-scale agriculture is constrained by reduced levels of non-agricultural income to draw on for purchase of farm inputs, and by starkly unequal world market conditions; state policies have favoured larger-scale commercial agriculture in some countries, and veered back and forth in their support to small-scale farming in others, such as Malawi and Mozambique; and pandemics such as AIDS and TB undermine the livelihood capacities of many.

On the other hand, rural poverty in South Africa today has features that make it unusual or extreme in the region. These include the significant, if declining, proportion of the rural poor who engage in wage labour on large-scale commercial farms; the even larger numbers of households in densely settled areas under 'customary' forms of land holding, who lack access to arable land, do not own livestock and do not engage in farming on any scale; the predominance of non-agricultural sources of income for almost all rural households; the absence of vibrant rural markets and dependence on mass-produced commercial foods; and the increasing importance of cash transfers from the state (social grants) as key sources of income. Some of these features derive from the specific character of historical processes of agrarian change in South Africa, as one component of its capitalist development more generally, others from specific policies adopted since 1994 (such as the massive expansion of social welfare grants). In contrast, in other countries in the region, small-scale agriculture, albeit differentiated, is still of vital importance to rural households, including the poor; fewer people work as wage labour on commercial farms; and cash transfers from the state are largely absent.

These differences are rooted in the historical span of South African colonization, the scale of its transition to capitalist agriculture and industry, the extent of African dispossession, the extreme racialization of its colonial political order and the uneven

\footnotetext{
${ }^{6}$ On the link between 'state nationalism' and such instances of popular xenophobia, see Neocosmos (2010).
} 
course of the post-apartheid political settlement. The question of agrarian reform in contemporary South Africa is thus posed in a context that differs from both that of the classic agrarian question and that in surrounding countries of the region. The links of South Africa's dispossessed to land and farming have been significantly eroded, but land remains a core focus of democratic politics and of efforts to establish social identity. To what extent can agrarian reform in South Africa address issues of employment, simple reproduction, poverty and inequality in contemporary conditions of structural 'surplus labour'?

Any answer to this question has to be placed within the framework of a regional political economy.

\section{The 'Classic' Southern African Dispossession/Accumulation Model}

Our understanding of the political economy of Southern Africa was shaped by the work of earlier scholars, many of them Marxists, who saw apartheid not as an aberrant Afrikaner innovation of 1948, but as the continuation and reworking of earlier forms of domination.They focused on the question of labour, and particularly on the pervasiveness, durability and eventual vulnerabilities of migrant labour (cf. Wolpe 1972; Amin 1974; Legassick 1974; Meillassoux 1975). They saw the constitution of the 'Native Reserves', both social and physical spaces, as central to the functioning of colonial capitalism. The account that they provided helped us to understand that the poverty and misery of black rural areas were not the residual result of an absence of development but, rather, manifested a particular pattern of capital accumulation on the back of land dispossession.

The proportion of land formally held by reserves in South Africa was very small - about 13 per cent of the country's land area according to the Land Act of 1936 - although African peasant production long survived in some settler rural areas through labour tenancy arrangements. Native Reserves occupied a much higher proportion of land in other countries of the region. Even in Southern Rhodesia (now Zimbabwe), settlers held less than half of arable land, though they took land with the greatest farming potential. It is easy to forget today that under the colonial dispensation some now independent countries were primarily labour reserves. Lesotho, Botswana and Swaziland, fashioned administratively into unified (and bounded) kingdoms, were effectively labour reserves for South Africa's mines. Parts of densely populated southern Malawi supplied workers, along with migrants from then Portuguese East Africa (Mozambique) in the first third of the twentieth century, to its settler tea and tobacco estates, to mines and commercial farms in the Rhodesias (Zimbabwe and Zambia), as well as to South African mines. Mozambique was carved into three socio-economic regions: the south as a labour reserve for the South African mines, the centre as a labour pool for its settler sugar and copra estates, and the north eventually as a domain of forced peasant cotton cultivation for the Portuguese textile industry.

In short, the labour reserve theorists saw as key to the profitability of capitalist enterprises in Southern Africa in the nineteenth century and much of the twentieth century the availability of cheap migrant labour, assured partly through the variable levels of dispossession of Africans from their land, partly effected by taxation and partly by 
coercive, state-managed systems of transnational recruitment. Cheap labour was available because children and dependants were nourished and cared for by the noncommodified work of rural women. Low wages were also sustained by the availability of cheap domestically produced food, much of it grown by peasants confronting highly regulated monopsonistic markets. In Gaza province in southern Mozambique, for example, women were obliged to cultivate rice as a cash crop that they were barred from eating themselves, while the men of their households were working contracts on the South African mines.

In this view, the highly 'dualistic' but unified economic structure was articulated with and dependent on the bifurcated colonial polity later described by Mamdani (see further below). Racial differences were articulated with those of class, gender and age, overseen by authoritarian political regimes charged with maintaining and extending law and order and the accumulation of capital, and reconciling it with the demands of the colonial metropoles and the privileges of the white settler minorities. South Africa was a regional centre of accumulation dependent on labour reserves both within and outside its own boundaries. It organized sites of accumulation throughout the region, drawing on scarce labour from rural reserves, paid below its costs of reproduction, and similarly governing through a decentralized and sharp political division between citizens and 'tribal' subjects. As the most important centre of capital accumulation in the region, South Africa developed the strongest industrial base and the most powerful commercial agriculture, which should not lead us to overlook the importance of mining capital in Zimbabwe, Zambia and Namibia, nor the relative strength of commercial agricultural enterprises, processors and trade monopolies in Zimbabwe, Mozambique, Zambia, Malawi and Swaziland.

\section{Structural Shifts from the 1970s: Towards 'Surplus Labour'}

At the time when they wrote in the 1970s, it was apparent to the scholars of the labour reserves that the system of migrant labour had eroded its own conditions of existence, a situation long signalled by South African government reports on erosion and declining food production in the worst affected Native Reserves. Demographic implosion and stagnant or declining farm production had vitiated the subsistence 'subsidy' of farming, thus threatening to undercut the cheapness of labour.

In retrospect, we can now see that the contradictions documented by analysts of the labour reserves made their own contribution to major shifts in the basis of capital accumulation in Southern Africa in the last decades of the twentieth century, arising from global as well as regional political, economic and demographic changes. As people continued to flow out of rural areas and demand for labour started to decline in mining and manufacturing, cheap labour was no longer scarce and securing it no longer required systematic state intervention. In the past 40 years, the emergence of evident growing 'surplus labour', unemployment and casualization have narrowed the range of employment-based entitlements, cut flows of remittances between rural and urban areas, and heightened competition for jobs and access to services. Urban migration is no longer politically managed. The meaning and terms of land use, the production of wealth and poverty, and patterns of inequality have shifted radically, though variably, across the region, within as well as between countries. 
If the question of labour is so radically reconfigured, what does the theorization of 'Africa of the labour reserves', in the term of Samir Amin (1976), have to offer to our understanding of the relation between agrarian reform and rural poverty today? Here, we note a common thread of critique, which we think is warranted (and which for some of us must also include an element of self-critique). In drawing the connections between dispossession and accumulation in an overly schematic manner, analysis could become functionalist and teleological, assuming that everything that exists represents in one way or another the logic of capital, thereby omitting the specific social and historical conditions of its self-expansion and domination, and similarly specific forms of contradiction and struggle that it generates and that confront it. For example, feminists such as Belinda Bozzoli (1983) pointed out early on that the pinning of women to the reserves was the product of an alliance between capital, colonial administrators and African elders/patriarchs, and that women did not necessarily acquiesce in the function of reproducing labour-power allocated to them. Flight to urban areas, and work as domestic servants or as shebeen (drinking house) owners and workers, could represent gendered forms of resistance.

In effect, much of the macro-structuralist analysis - focused on the functions of rural areas for accumulation - drifted into economism and displayed little interest in the social dynamics and differences of Southern African countrysides, how they were experienced, and forms of collective agency constructed from those experiences. There was a tendency to treat the reserves, or Bantustans, or (now) 'the former reserves/Bantustans', as both homogeneous and residual: where people can be drawn from when needed and dumped when they are not (that is, exactly what capital and the apartheid state wanted them to be). On the contrary, it is necessary to grasp the diversity and differences of the rural areas of Southern Africa, and the complex social dynamics, including divisions of class, gender and generation among their inhabitants. Their histories, both past and future, are not written by capital alone. One key critic of the overly economic analysis of the labour reserve theorists is Mahmood Mamdani; while, in turn, his overly political focus has been criticized for neglecting the sociocultural dynamics among rural 'subjects' and the contradictions of control through 'custom'.

\section{South Africa since 1994 and its challenges The Moment of 'Transition'}

In 1992, Mahmood Mamdani first visited South Africa as part of a small group of African social scientists invited to attend a symposium on research and the transformation of South African society. One aspect that struck the visitors was the pervasiveness and tenacity among both academics and politicians of the presumption that South Africa's experience is exceptional. South Africa's history, and particularly its patterns of economic development, were considered so distinctive that it was thought by many, and not least African National Congress (ANC) intellectuals, to have more in common with Brazil or the Asian tigers than with the rest of Africa. 7 Mamdani's unease with this view and its consequences was first outlined in an insightful article in the Economic and Political Weekly (Mamdani 1992) and then developed in Citizen and Subject (Mamdani 1996), his masterly reflection on the distinctive character of colonial rule in Africa and its effects for the forms of the polity, and for democracy, after independence. He concluded that if one looks only at the labour question, South Africa's high

\footnotetext{
${ }^{7}$ Did this represent an aspiration to, or fantasy of, a post-apartheid future? In any case, it served as another marker of South African 'exceptionalism' within the region and sub-Saharan Africa more generally. Contrasts between Southern African 'accumulation by dispossession', above all dispossession of land, and East Asian experiences of industrialization, are explored and argued by Hart (2002) and Arrighi et al. (2010).
} 
levels of industrialization and proletarianization make it exceptional in sub-Saharan Africa, but that proper attention to the political question of domination shows that apartheid was the crystallization, even the perfected form, of the bifurcated state generic to sub-Saharan Africa's modern history. This view was, in effect and if mostly implicit, a criticism of positions on colonialism that centred exclusively on the labour question, including the 'classic' dispossession/ accumulation model (above) applied to South Africa and other settler colonies. Mamdani feared that if the structure of indirect rule were left intact, with native authorities left in charge of an ethnically governed rural population, free movement between town and country and South Africa's strong urban civil society would not be sufficient to dislodge the anti-democratic legacy of apartheid even when formally de-racialized, as it has been since 1994 .

Mamdani rightly attributed great importance to the character of colonial rule across subSaharan Africa as both racialized and tribalized in ethnically constituted polities. While the former was formally ended with independence from colonial rule, the legacies of the latter, he argued, are embedded in the endurance of the rural-urban divisions that continue to mark forms of both domination and resistance. In our view, escaping the hermetic analytical clutches of exceptionalism, while recognizing what is specific and different in the South African case, demands transcending Mamdani's binary of distinct questions of labour and domination, as respectively 'economic' and 'political'. Both questions are political and economic, and their historical foundations and social dynamics take us beyond the territorial boundaries of the countries of the region to look at their interconnections. ${ }^{8}$

Almost 20 years on, Mamdani's fears about the durability of the legacy of apartheid seem prescient as near-segregation still dominates so many areas of everyday life in South Africa, manifested in racialized patterns of employment, residence, transport, shopping, music, worship, friendship, health care, education and voting. ${ }^{9}$ In short, the 'historic compromise(s)' through which apartheid ended in 1994 introduced political democracy while leaving the inherited structures of economic and social power largely intact. Moreover, the pressures of party politics has reinforced a potent politics of ethnic ('tribal') governance, pursued by CONTRALESA, and not least concerning rights over 'communal' land in the former Bantustans (see further below; see also Claassens, this issue).

\section{Since 1994: Land Reform and Agrarian Change}

Land reform in South Africa has run into deep problems: it remains a political tinderbox but has raised a host of challenges to its economic rationales and its implications for justice and equity.

The reconstruction of an agrarian structure dominated by large-scale commercial farms was not clearly articulated as an objective in post-1994 policy documents such as the Reconstruction and Development Programme (ANC 1994) or the White Paper on South African Land Policy (RSA 1997), but over the past decade has become an explicit goal

\footnotetext{
${ }^{8}$ For fuller critical discussions of Mamdani's thesis from a materialist perspective, see O’Laughlin (2000) and Capps (2010, ch. 1 and cf. Neocosmos 2010).

${ }^{9}$ Deploying aWeberian notion of class, Seekings and Nattrass (2005) argue that (cross-racial) class formation is displacing racialized social divisions, a dynamic that started before the end of apartheid in their view. For class formation among South Africa's black population, seeWolpe (1988); and in the region's countrysides, Neocosmos (1993), Levin and Neocosmos (1989) O'Laughlin (1996), Peters (2002, 2011), Scoones et al. (2010), Cousins (2011) and in this issue.
} 
of government policy. ${ }^{10}$ It was strongly emphasized in a resolution on rural development, land reform and agrarian change adopted by the ruling ANC at its Polokwane national conference in 2007 (ANC 2007), which informed the naming of land reform and rural development as one of the current Zuma government's five priorities in 2009.

In relation to land redistribution, the initial target was to redistribute 24.6 million hectares (i.e. 30 per cent) of white-owned agricultural land by 1999, through both grants-based redistribution and a rights-based restitution programme. By the end of 1999, less than a million hectares had been transferred (around 1.2 per cent of white-owned farm land), and the target date was subsequently revised to 2014 (Jacobs et al. 2003, 5). By March 2011, however, only 7.2 per cent (6.3 million hectares) had been transferred, and the official target date for achieving the 30 per cent target has now been set at 2025 . Large rural land restitution claims are proving difficult to settle, in part because of the high costs involved (Lahiff 2008; Greenberg 2010).

In relation to the impacts of land reform on the income and livelihoods of beneficiaries, the available evidence is far from comprehensive, and criteria and indicators have varied greatly between studies (Hall 2009, 40-4). Claims that '90 percent of land reform projects have failed'11 are exaggerated, but it is clear that cases of dramatic improvements are few and far between.

Most studies report that redistributed and restored land tends to be underutilized by beneficiaries, in part because of low levels of post-settlement support services, inadequate access to capital and inappropriate planning by officials and consultants (ibid., 44). The third leg of land policy is tenure reform, which seeks to secure the land rights of farm workers, labour tenants and residents in 'communal areas' under 'traditional' systems. New legislation and policies have generally failed to achieve this objective (Claassens and Cousins 2008). It is now widely claimed that land reform is on a 'road to nowhere', ${ }^{12}$ a departure point for populist formations such as the ANC Youth League to begin to link land confiscation to wider demands for nationalization of minerals and other resources (Herskovitz 2011).

In relation to reform of agrarian structure, large commercial farms continue to produce almost all marketed agricultural production (Vink and van Rooyen 2009, 15). Little has changed since 1994, when they accounted for 90 per cent of value added in agriculture (Word Bank 1994, 22). By 2002, large farms received 99.7 per cent of all profits made from farming (Makgetla 2010, 32). The massive levels of state support that white farmers received under apartheid started to be reduced from the mid-1980s as part of apartheid 'reform', and were slashed to almost zero by post-1994 deregulation and liberalization policies.The effects of these 'market reforms' has been further concentration of both commercial farm ownership and production (see Bernstein, this issue). Some large farms have been purchased by black South Africans with access to

\footnotetext{
${ }^{10}$ The Land and Agrarian Reform Project: Concept Document (RSA 2008); Lahiff (2008).

${ }^{11}$ Such claims have been made, somewhat bizarrely, by the Minister of Rural Development and Land Reform, Gugile Nkwinti, but no empirical evidence to back up these claims has been made available (Lund 2012).

12 'Land reform. A road to nowhere', Financial Mail, 29 July 2011.
} 
capital, but how many remains unclear. Alongside deregulation and concentration, employment on commercial farms has also dropped, from 1.1 million in 1993 to 800,000 in 2007 (Makgetla 2010, 36: see also Bernstein, this issue; Hall et al., this issue).

Commercial farming remains relatively labour-intensive, however, employing 8-9 per cent of the national employed labour force, despite a relatively low contribution to GDP of around 3 per cent (Vink and van Rooyen 2009, 30). But fewer farm jobs are now 'permanent'; more are seasonal and casual in nature; in some regions, the supply of labour is outsourced to labour brokers; and commercial farms in parts of the country draw on the cheapest of labour migrants from Mozambique, Lesotho and Zimbabwe. Many farm workers have been evicted from farms despite land reform legislation, and are now resident in informal settlements or in small rural towns (Wegerif et al. 2005; Atkinson 2007). Agricultural production grew by 1.5 per cent per year, on average, from 1994 to 2008, which was slower than the rate of growth of GDP in general, at 3.8 per cent (Makgetla 2010, 32) and has not kept pace with population growth. Commercial agriculture has become increasingly integrated into global markets for both inputs and outputs, and commercial farm revenues are thus strongly influenced by global conditions and exchange rates.The share of total output from horticulture has increased by 4 per cent since the early 1990s, to some degree at the expense of field crops and livestock, and many farmers have diversified their production systems as a risk management strategy (Vink and van Rooyen 2009, 7-8).

At the other end of the spectrum, around 2.5 million black rural households, mostly located in the former Bantustans, engage in some form of farming, mostly to produce some food for their own consumption (Aliber and Hall 2010, 13). Between 250,000 and 300,000 black farmers derive some cash income from agriculture, and are sometimes seen as 'commercially oriented', but many of these, including those on irrigated land, struggle to do more than 'get by' (ibid., 14). In effect, the agrarian dualism that is deeply rooted in South Africa's distinct trajectories of capitalist accumulation has been reproduced after the end of apartheid. Some critics argue that, in part, this is because land reform policies have deliberately sought to maintain 'viable' large farms and have neglected the option of supporting smallholder production for both household consumption and the market (Lahiff 2007; Hall 2009; Cousins and Scoones 2010).

In the former Bantustans, the area of arable land that is not cultivated appears to be increasing, in part because of lack of access to draught power, capital to purchase crop inputs and fencing to protect fields from livestock (Andrew et al. 2003). Although the absolute number of households engaged in farming of some kind appears to be relatively stable (Aliber and Hall 2010), the proportion is declining as the population grows and many households lack access to fields. Because of rising levels of unemployment, both wages and remittances from employed family members in urban areas or elsewhere have declined as a source of rural income. Social grants - including non-contributory needsbased old age pensions, child support and disability grants - expanded rapidly after 1994 . In 2007, almost 43 per cent of South African households received at least one social grant; by 2010, they were being paid to around 14 million people, or nearly a third of the population, with a total monetary value of around 3.5 per cent of GDP (Marais 2011, 238).

https://repository.uwc.ac.za/ 
In effect, social grants have become the most significant source of income for many rural households (Neves et al. 2009). Health facilities have expanded in rural areas, but staff and resources are strained by the high proportion of rural people living with endemic diseases such as AIDS and tuberculosis. At the same time, the patterns of rural household organization identified with historic migrant-labour systems, particularly the growing propor- tion of women-headed households, continue to predominate and marriage rates continue to decline (Mhongo and Budlender n.d.).

To conclude, Makgetla (2010, 22-8) summarizes trends in the former Bantustans as follows:

... despite relatively rapid growth [of incomes], the share of the former Bantustans in the GDP increased from only 12 per cent to 14 per cent between 1995 and 2008, and incomes continued to lag behind the rest of the country ... about half of the increase occurred in unearned income [that is, government transfers and remittances] . . in 2007 they housed around half of African children and pensioners, but only a third of workingage Africans ... and women constituted 57 per cent of the adult population, compared to 50 per cent in the rest of the country ... government and the informal sector, which was mostly retail, contributed just over half of all employment, compared to 40 per cent in the rest of the country ... most people remained in a poverty trap.

\section{Further questions, and the papers}

Locating the question of agrarian reform in South Africa within the broader historical and regional perspective that we have sketched brings a series of questions to the foreground of politics, some of which are discussed in this issue. All are concerned not just with the current situation and what has produced it, but with the dynamics of change, and what we can realistically expect agrarian reform to mean in South Africa.

\section{What Can Agrarian Reform Achieve?}

As implied earlier, answers to this question depend in part on how it is framed theoretically. Therefore, we do not expect answers to converge - and, indeed, would probably not share the same answer ourselves. Our purpose here is not to create a political consensus, but to clarify issues that lie behind the question and that must be made explicit in trying to answer it. Although few would challenge the political impact that a dramatic redistribution of agricultural land would have in South Africa, its likely effects on rural livelihoods are as often obscured as they are fiercely debated. This is strongly argued by Andries du Toit, who proposes freeing the debate of land reform from much of its discursive construction (and obsessions with ownership) to date in order to situate it more centrally, and productively, in the broader problematic of social inequality in South Africa.

\section{What Is Happening to Patterns and Scales of Ownership, Use of Land, Labour Recruitment Conditions of Work and Forms of Subsidy in Commercial Agriculture in South Africa?}

Agricultural land has a social form - it comes with patterns of cropping and livestock keeping, infrastructures, workers and ways of working. When we speak about land redistribution, we thus have to consider not just matters of ownership of land, but also 
the reworking of this social landscape. South Africa has a regionally diverse organization of commercial arable and livestock farming and a long history of restructuring agriculture. The image of the large-scale mechanized grain producer, heavily supported by government subsidies through the co-operatives and grain boards, applied to a particular period, never characterized the entire country and has been reworked since 1994 . What about the concentration of holdings, the conversion of land out of agriculture, the organization of the kinds of outgrower schemes now developing so rapidly elsewhere in the region, and the movement of South African agrarian and agribusiness capital into other countries of the region? Henry Bernstein's paper in this issue provides an overview of some of these processes since 1994 .

\section{What Are the Present Conditions of Work and Living of Agricultural Workers and Their Families?}

In contemporary South Africa, many of those who live from agricultural production are wage workers on commercial farms. On this basis, Sender and Johnston (2004) argue that agrarian reform would be better conceived as a strategy to expand wage employment and to improve the conditions of workers on commercial farms, rather than as a radical redistributive shift in the ownership of agricultural land. Whatever the vision of agrarian reform, it will affect farm workers. Recent experience in Zimbabwe demonstrates the importance of taking their interests into account, its thorny politics and the costs of failing to do so. Many of South Africa's agricultural workers are migrants from Mozambique and now, increasingly, from Zimbabwe.

To what extent have broader shifts in the organization of commercial farming entailed different patterns of labour recruitment, use, and conditions of work and residence? How have changes affected the dynamics of workers' households and the situation of children? Do rural households combine farm work with off-farm activities? What have been the spin-off effects of changes in farm work on small rural towns? Has the democratic dispensation affected the aspirations and forms of organization of agricultural workers? How different are the conditions of workers on white- and black-owned and operated farms? These questions require far more research, and answers to them would reveal different patterns across South Africa's rural landscapes. Some idea of the complexities involved, and which enriches Bernstein's broad overview, is provided by Ruth Hall, Poul Wisborg, Shirhami Shirinda and Phillan Zamchiya, from their research in Limpopo. In the nature of the case, their study does not give generalizable answers, but it does yield some generalizable cautions about common assumptions concerning the places(s) of farm workers, and farm dwellers, in agrarian reform.

\section{What Forms of Authority and Land Ownership Govern the Relation between People and Land?}

Mamdani's analysis of the link between the bifurcated state and racial domination (above) raises very sharply the question of what forms of governance should apply under regimes of agrarian reform. To one extent or another, this question confronts all countries of the region, but with particular acuity in those with substantial land held by settler farms and large multinational enterprises. It also applies in the renegotiated status of 'public land', not just forest or conservation reserves but also mineral rights (on the land question in relation to platinum mining in Bafokeng, see Capps 2010). 
This question has already arisen in the limited experiences of land restitution and redistribution undertaken in South Africa, as it does in Zimbabwe. Moreover, unless agrarian reform were simply to mean the redrawing of lines of bifurcation, it implies a reconsideration of the negotiated accord with CONTRALESA around the role of chiefs in governance of land and people in the former reserves. How existing forms of authority, power and governance concerning land function in the former reserves is explored in this issue by Aninka Claassens, with special reference to recent changes in single women's land rights and contestations over customary law in South Africa. She draws on debates about 'living customary law' to suggest how written and non-written norms are deployed in a social universe that is legally plural but shaped by the socially differentiated strategies of everyday life. Her study illustrates how dangerous it is to treat 'customary law' as a homogeneous category of rules and practices, reducing the variation in forms of rural governance, marriage and property to a single object of policy defined outside the realm of democratic politics.

\section{What Are the Possibilities of Making a Better Living from the Development of Small-Scale Farming and Accumulation in the Former Reserves?}

Another group working in agrarian production, and living from it to different degrees, are those farming in the former reserves, typically combined with access to non-rural sources of income and savings, be they from migrant wage labour and/or social grants, as David Neves and Andries du Toit demonstrate. They show that such non-rural (and rural off-farm) sources of income and savings have major implications for social reproduction, and play an important part in shaping social differentiation by class and gender in the countrysides of the 'homelands'.

Although it is sometimes presumed that redistribution of land should be based on collective ownership and operation of large-scale units, with existing forms of cropping, marketing and labour organization remaining in place (see Hall et al., this issue), another alternative could be the division of large farms and plantations into smallholdings. This makes a careful look at existing smallholder production in the reserves particularly important. Much literature on the reserves traces the processes through which they became densely populated zones with eroded and infertile soils and marginal water resources, essentially no more than residential areas for the families of migrant workers. Since 1994, the proportion of arable land under cultivation in the reserves has declined, yet in some areas some people have been able to maintain agricultural and livestock production as an income-earning activity. Indeed, the scale of holdings, infrastructure, soil quality, the availability of water and linkages with off-farm sources of income can allow some investment and accumulation to take place in small-scale agriculture.

Ben Cousins writes about one such area in KwaZulu-Natal, using it to inform and assess the possibilities and limitations of 'accumulation from below'. He shows that accumulation in small-scale farming is constrained in former labour reserves, and argues that expanded access to land and water is a necessary but not sufficient condition for such accumulation.

\section{What Is the Impact of Land Reform on Rural Livelihoods?}

Is it possible that any radical redistributive land reform in South Africa could lead to declines in household income through the drying up of wage-labour opportunities in agriculture, as well as decline in aggregate net food supply, and especially net marketed food supply? There are 
grounds for doubt: the current marginal involvement of rural households in agricultural production in many areas of South Africa, the overwhelming importance of social grants and off-farm activities as sources of rural income (Neves and du Toit, this issue), and the statistical evidence on the declining proportion of arable land under cultivation in the former reserves. The promise held out for some restitution schemes is that income from rent and mineral rights will yield much greater income benefits than agricultural production by those who receive shares in land ownership.

In this context, recent research by PLAAS on rural livelihoods following land reform is important and informative. Michael Aliber and Ben Cousins report and reflect on some of this research, drawing out similarities and differences with Zimbabwe and Namibia, recognizing that beneficiaries of land reform are differentiated by class and gender in their scales and types of agricultural production and the resources that they bring to farming.

\section{Are There Alternative or Complementary Ways beyond Agrarian Reform to Address the Problems of Rural Poverty in Southern Africa Today?}

The argument that ownership of agricultural land will lead to a major improvement in well-being for rural people in South Africa depends on a number of assumptions discussed in the papers in this special issue. These include the presumption that people with farming skills do not have land, or sufficient land to make a living from it, and that the existing land and water resources of South Africa can sustain rural livelihoods for many new small-scale farmers. James Ferguson reminds us that whatever the political and symbolic importance of land ownership in South Africa, it is still a means to an end, not an end in itself. If that end is a better quality of life, why assume that people must work the land to attain it? South Africa has many other forms of wealth, derived from resources that theoretically belong to all the people of South Africa. Why not proceed directly to redistributive schemes to eliminate poverty? Ferguson observes that non-contributory social transfers are effective in reducing poverty, particularly in rural areas, reaching many people beyond the named beneficiaries. He makes a strong plea for basic income grants, much debated in South Africa but rejected by its government. His main points are that land has many uses and benefits for the different categories of the poor beyond farm production, and that distributive justice in South(ern) African conditions, as elsewhere, demands a direct redistribution of wealth.

The profound inequality revealed by measures of income in South Africa are important because in a commodified society they indicate that some people will be able to enjoy better housing, better food, better schools and better health care. There is a rich literature that documents inequalities along all these dimensions between rural areas, informal settlements, townships and affluent suburbs. Education and health care can thus be loci where the kind of redistributive processes that Ferguson advocates take place. O'Laughlin argues that the quality of health is above all a reflection of the conditions of everyday life and work. These are affected by curative care but are first of all the outcomes - the social costs - of different ways of organizing production, different forms of social relations of production and reproduction. She deploys some of the historical literature on tuberculosis, malaria and nutrition in the region to propose connections between forms of ownership, the organization of work and the quality of 
health. Drawing on illustrations from Mozambique, Swaziland and South Africa, she shows that different forms of ownership and use of land have entailed both different health problems and different forms of political struggle against them. 


\section{References}

Aliber, M. and R. Hall, 2010. Development of Evidence-Based Policy around Small-Scale Farming. Programme to Support Pro-Poor Policy Development, The Presidency. Pretoria: The Presidency, South Africa.

Altman, M., T. Hart and P.Jacobs, 2009. 'Household Food Security Status in South Africa'. Agrekon, 48 (4): $345-61$.

Amanor, K., 2010. 'Family Values, Land Sales and Agricultural Commodification in South-Eastern Ghana', Africa, 80 (1):104-25.

Amin, S., 1974. 'Modern Migrations in Western Africa'. In Modern Migrations in Western Africa, ed. S. Amin, 65-124. London: Oxford University Press.

Amin, S., 1976. Unequal Development: An Essay on the Social Formations of Peripheral Capitalism. Hassocks: Harvester Press.

ANC (African National Congress), 1994. The Reconstruction and Development Programme. A Policy Framework. Johannesburg: ANC.

ANC (African National Congress), 2007. 'Resolution on Rural Development, Land Reform and Agrarian Change'. Resolution adopted at the 52nd National Conference, Polokwane, http://www.anc.org.za/ancdocs/history-conf/ conference52/resolutions-f.html (accessed 22 August 2012).

Andrew, M., A. Ainslie and C. Shackleton, 2003. 'Evaluating Land and Agrarian Reform in South Africa: Land Use'. PLAAS Occasional Paper No. 8 in the Land Reform Series. Programme for Land and Agrarian Studies, University of the Western Cape, Cape Town.

Arrighi, G., N. Aschoff and B. Scully, 2010. 'Accumulation by Dispossession and Its Limits: The Southern Africa Paradigm Revisited'.Studies in Comparative International Development, 45:410-38.

Atkinson, D., 2007. Going for Broke: The Fate of Farm Workers in Arid South Africa. Cape Town: HSRC.

Bernstein, H. ed., 1996a. The Agrarian Question in South Africa. Special issue of Journal of Peasant Studies, 23 (2-3). Bernstein, H., 1996b. 'The Agrarian Question in South Africa: Extreme and Exceptional?' Journal of Peasant Studies, 23(2-3):1-52.

Bozzoli, B. 1983. 'Marxism, Feminism and South African Studies'. Journal of Southern African Studies, 9 (2): $139-71$.

Capps, G.J., 2010. Tribal Landed-Property:The Political Economy of the Bafokeng Chieftancy, South Africa, 1837-1994. PhD thesis, London School of Economics and Political Science.

Chauveau, J-P. and P. Richards, 2008. 'West African Insurgencies in Agrarian Perspective: Côte d'Ivoire and Sierra Leone Compared'. Journal of Agrarian Change, 8 (4): 515-52.

Cousins, B., 2011.'What Is a 'Smallholder'? Class-Analytic Perspectives on Small-Scale Farming and Agrarian Reform in South Africa.' In Land Resource Reform in South Africa: Impacts on Livelihoods, eds P. Hebinck and C. Shackleton, 86-111. Abingdon: Routledge.

Claassens, A. and B. Cousins, eds, 2008. Land, Power and Custom: Controversies Generated by South Africa's Communal Land Rights Act. Cape Town: UCT Press/Athens, OH: Ohio University Press.

Cousins, B. and I. Scoones, 2010. 'Contested Paradigms of "Viability" in Redistributive Land Reform: Perspectives from Southern Africa'. Journal of Peasant Studies, 37 (1):31-66.

Greenberg, S., 2010. Status Report on Land and Agricultural Policy in South Africa, 2010. Research Report 40. Cape Town: Institute for Poverty, Land and Agrarian Studies, School of Government, University of the Western Cape.

Hall, R., 2009.'Land Reform for What? Land Use, Production and Livelihoods'. In Another Countryside. Policy Options for Land and Agrarian Reform in South Africa, ed. R. Hall, 23-61. Cape Town: 
Institute for Poverty, Land and Agrarian Studies, School of Government, University of the Western Cape.

Hall, R., 2011. The Politics of Land Reform in Post-Apartheid South Africa, 1990 to 2004: A Shifting Terrain of Power, Actors and Discourses. DPhil thesis, University of Oxford.

Hart, G., 2002. Disabling Globalization. Places of Power in Post-Apartheid South Africa. Pietermaritzburg: University of Natal Press.

Herskovitz, J., 2011. 'S. Africa's Malema Calls for Massive Land Grab. Reuters Africa, 5 May, http://afreuters.com/ topNews/idAFJOE7740LL20110505(accessed 19 October 2011).

Jacobs, P., E. Lahiff and R. Hall, 2003. 'Evaluating Land and Agrarian Reform: Land Redistribution'. Occasional Paper Series No. 1. Cape Town: Institute of Poverty, Land and Agrarian Studies, University of the Western Cape.

Lahiff, E., 2007. "Willing Buyer,Willing Seller”: South Africa's Failed Experiment in Market-Led Agrarian Reform'. Third World Quarterly, 28 (8): 1577-98.

Lahiff, E., 2008. Land Reform in South Africa: A Status Report 2008. Cape Town: Institute of Poverty, Land and Agrarian Studies, University of the Western Cape.

Legassick, M., 1974. 'South Africa: Capital Accumulation and Violence'. Economy and Society, 3 (3): 25391.

Levin, R. and M. Neocosmos, 1989. 'The Agrarian Question and Class Contradictions in South Africa: Some Theoretical Considerations'. Journal of Peasant Studies, 16 (2): 230-59.

Lund, T., 2012. 'SA Not Reaping Benefits of Land Reform'. Financial Mail, http://www.fm.co.za/politics/2012/08/08/sa-not-reaping-benefits-of-land-reform (accessed 14 August 2012).

Makgetla, N., 2010. 'Synthesis Paper: South Africa'. Unpublished paper prepared for a meeting on rural development in India, Brazil and South Africa.

Mamdani, M., 1992. 'Africa: Democratic Theory and Democratic Struggles'. Economic and Political Weekly,27 (41): 2228-32.

Mamdani, M., 1996. Citizen and Subject: Contemporary Africa and the Legacy of Late Colonialism. Cape Town: David Philip.

Marais, H., 2011. South Africa Pushed to the Limit: The Political Economy of Change. Cape Town: UCT Press. Meillassoux, C., 1975. Femmes, Greniers et Capitaux. Paris: Maspero.

Mhongo, C., and D. Budlender, n.d. 'Declining Rates of Marriage in South Africa: What Do the Numbers and Analysts Say?' Acta Juridica.

Miller, D., 2008. "Retail Renaissance" or Company Rhetoric:The Failed Partnership of a South African Corporation and Local Suppliers in Zambia'. Labour, Capital and Society, 41 (1): 34-55.

Neocosmos, M., 1993. The Agrarian Question in Southern Africa and "Accumulation from Below": Economics and Politics in the Struggle for Democracy.Uppsala: Nordiska Afrikainstitutet.

Neocosmos, M., 2010. From 'Foreign Natives' to 'Native Foreigners'. Explaining Xenophobia in Post-Apartheid South Africa: Citizenship and Nationalism, Identity and Politics, 2nd edn. Dakar, Senegal: Codesria.

Neves, D., M. Samson, I. van Niekerk, S. Hlatshwayo and A. du Toit, 2009. The Use and Effectiveness of Social Grants in South Africa. Research Report. Johannesburg: FinMark Trust.

O’Laughlin, B., 1996. 'Through a Divided Glass: Dualism and the Agrarian Question in Mozambique'. Journal of Peasant Studies, 23 (4):1-39.

O'Laughlin, B., 2000. 'Class and the Customary: The Ambiguous Legacy of the Indigenato in Mozambique'. African Affairs, 99 (394): 5-42.

Peters, P.E., 2002. 'Bewitching Land: the Role of Land Disputes in Converting Kin to Strangers and in Class Formation in Malawi', Journal of Southern African Studies, 28 (1):155-178. 
Peters, P.E., 2011. 'Rural Lives and Deepening Inequality: The Case of Malawi'. Paper presented to Colloquium on Land Reform,Agrarian Change and Rural Poverty,STIAS, 8-9 March 2011.

Philip, K., 2009. Second Economy Strategy: Addressing Inequality and Economic Marginalisation. A Summary Overview. Pretoria: The Presidency, South Africa.

RSA, 1997. White Paper on South African Land Policy. Pretoria: Department of Land Affairs.

RSA, 2008. The Land and Agrarian Reform Project: Concept Document. Pretoria: Ministry of Agriculture and Land Affairs. Scoones, I., N. Marongwe, B. Mavedzenge, J. Mahenehene, F. Murimbarimba and C. Sukume, 2010.Zimbabwe's Land Reform. Myths and Realities. Woodbridge: James Currey.

Seekings, J. and N. Nattrass, 2005. Class, Race and Inequality in South Africa. New Haven, CT: Yale University Press. Sender, J. and D. Johnston, 2004. 'Searching for Weapons of Mass Production: Unconvincing Arguments for Land Reform'. Journal of Agrarian Change, 4 (1-2): 142-64.

Standing, G., J. Sender and J. Weeks, 1996. Restructuring the Labour Market: The South African Challenge. Geneva: ILO. Vink, N. and J. van Rooyen, 2009. 'The Economic Performance of Agriculture in South Africa since 1994: Implications for Food Security'. Development Planning Division Working Paper Series No. 17. Midrand: Development Bank of Southern Africa.

Walker, C., 2008. Landmarked: Land Claims and Land Restitution in South Africa. Johannesburg: Jacana.

Wegerif, M., B. Russell and I. Grundling, 2005. Still Searching for Security:The Reality of Farm Dweller Evictions in South Africa. Polokwane North and Johannesburg: Nkuzi Development Association and Social Surveys.

Wolpe, H., 1972. 'Capitalism and Cheap Labour Power: from Segregation to Apartheid'. Economy and Society, 1(4): 425-56.

Wolpe, H., 1988. Race, Class and the Apartheid State. London: James Currey.

World Bank, 1994. South African Agriculture: Structure, Performance and Options for the Future. Washington, DC: The World Bank. 